\title{
Influence of Pester Power on Parents' Buying Decision: A Focus on FMCG Products in Pakistan
}

\author{
Munir A. Abbasi ${ }^{1}$, Azlan Amran ${ }^{1}$, Hadiqa Riaz ${ }^{2}$, Noor e Sahar ${ }^{3} \&$ Hassan Ahmed $^{4}$ \\ ${ }^{1}$ Graduate School of Business, Universiti Sains Malaysia (USM), 11800, Penang, Malaysia \\ ${ }^{2}$ Muhammad Ali Jinnah University Karachi, Pakistan \\ ${ }^{3}$ Benazir School of Business, BBSUL, Karachi, Pakistan \\ ${ }^{4}$ Barrett Hodgson University Karachi, Pakistan \\ Correspondence: Munir A. Abbasi, Graduate School of Business, Universiti Sains Malaysia (USM), 11800, \\ Penang, Malaysia. E-mail: munyeer@yahoo.com
}

Received: April 3, $2020 \quad$ Accepted: May 6, $2020 \quad$ Online Published: May 9, 2020

doi:10.5539/ijms.v12n2p115 URL: https://doi.org/10.5539/ijms.v12n2p115

\begin{abstract}
This study examined the impact of pester power on parent's buying decisions, considering the peer influence, store environment, product packaging, and advertisement as stimuli of pester power. Data were collected by distributing a survey questionnaire in supermarkets and shopping malls in Pakistan from 200 parents and were analyzed by using PLS-SEM. The results confirmed the Pakistani children's dominance in parents buying decisions for various Fast-Moving Consumer Goods (FMCG) products. The results significantly indicate that product packaging, peers' product preferences, and advertisements affects parents buying decision. The findings of this study contribute to the existing literature on the impacts of pester power on the parents buying decisions through peer influence, product packaging, and advertisement. In addition to that, this study is the first attempt in the Pakistan context, especially the FMCG industry. The findings of this study may benefit marketers to increase their market share by developing their strategies and marketing campaign; and store managers to plan product placement in their stores in such a way that cultivates quest in children for products, considering them as influencers on parents buying decisions, in line with the study findings.
\end{abstract}

Keywords: FMCG, parents buying decision, pester power, Pakistan

\section{Introduction}

Children are the most valuable and influential part of a family and always get more significant attraction and love from their parents. Targeting children to influence their parents or other family members is the key to business growth. Parents want their children happy, and children have the power to persuade their parents to fulfill their desires, whether it is essential or not. Because of the increasing trend of a nuclear family, children become more pampered, and this makes them more obstinate about their product choices. They want products, whether it is for their personal use or not. This nagging ability of children to force the purchase decisions of their family is called "Pester Power."

Pakistan statistics bureau (2019), Children between 3-15 years of age constitute $30.76 \%$ of the total of Pakistan's population (204.73 million). These children do not have a direct purchasing power; however, they possess opportunities to influence the family purchase. Lawlor (2018) instilled that childhood buying patterns and choices may transfer into adulthood buying. Association and familiarity with the brands at an early age may heavily influence their buying practices as a mature customer. Viviers and Botha (2019), pester power is the ability of children to affect or even change the buying behavior of their parents on behalf of some reasons. However, Warc (2018) presented another perspective and anticipated that modern parents looking for children's guidance and cooperation in shopping, rather than considering it as a nagging factor. Jain and Sharma (2016) defined pester power is the tendency of children to pester a family member continuously until the mum or dad accede and agrees to the demand.

In today's digital world, children become more aware of the latest technology, and they better know what is going on in their surroundings. It has become very challenging for parents to convince children to follow their choices. Children often demand those products advertised in the mass media and especially in social media. 
Mass media and digital media have an massive influence on children's daily lives. Media is considered the main factor behind children nagging power and provides children's more essential means of information and influences their buying behavior. Advertisements have revolutionized children learning and behaving power to a broader level. Children are receiving more about the latest products, mainly through advertisements. As now, the children have financially blessed; they turn into more independent regarding their buying decisions (Dikčius et al., 2019; Lati, Abrar, \& Ali, 2017).

Thomson, Laing, and McKee (2007) inferred that marketers are captivating children to force their parents to acquire products that are not of their choice, or they do not have purchasing power for it. Children have become the most attractive target market for marketers for several reasons. Thomson et al. (2007), a child with two years of age, can design their demands, and when they become four years old, they can categorize their preference and show their likes and dislikes. As they turn five years old, they accept peer influence, like specific stores to shop, gather information about their favorite brands and pester their parents to buy specific brands for them. Marketers have understood the nagging power of children as to how influential children are in family buying decisions. The main aim behind pesters power marketing is to target children to pressurize or pester their families in purchasing different products.

The objective of this paper is: 1) to explore the influence of pester power on parents buying decisions for FMCG products and will also reveal the significant factors that help in building up pester power, 2)to investigate the relationship between pester power and parents buying decision of FMCG products, 3) to identify the factors that impact children to influence parents buying decisions and, 4) to determine whether pester power in children was nurtured due to their exposure to advertisement.

In the past several studies have been conducted to examine how children pester their family purchase decisions. Arul (2016) opined that kids use various persuasive strategies to pester their parents. They do not care about product performance, durability, attributes, price, and more; instead, they go for product visibility and packaging. Calvert (2015) inferred that children's request for items to their parents depends on the nature of their persuasive strategies. Moreover, Ogba and Johnson (2010) examined that, child's age and gender, product packaging, child's growth stage, parent's purchasing power, size of the family, appropriate use of products and, price of the products are some causes to determine the number of items, a child demand. Nicholls (2014) delineated that, irrespective of any society or culture, kids are the most substantial part of a family and have significant influence over parents buying decisions.

With the increasing number of hypermarkets and supermarkets, this household chore is seen as fun and family outing (Ramzy, Ogden, \& Zakaria, 2012). McNeal (2016) inferred that kids below than twelve years of age, make more than fifteen demands per family buying and when it is combined with the demands they have made at home, it becomes approximately 3000 demands each year. Multiple pieces of research (Arul \& Vasudevan, 2016; Calvert, 2015; Lawlor \& Prothero, 2011) have been conducted to determine the role of pester power on family buying decisions in different countries. This study has plugged the gap in the academic literature by critically studying the different aspects of pester power individually like peer influence, packaging, store ambiance, and advertisement considering their impact on parents buying decisions for fast-moving consumer goods in Pakistan. The results would help marketers to identify various factors that help to influence children's nagging ability. This study will also provide an insight view of the children buying behavior and the factors which contribute to developing pester power.

\section{Literature Review}

The family buying decision theory has been referred to elucidate the pester power influence on the parent buying decision of FMCG (Sheth, 1974). Multiple studies (Chaudhury \& Hyman, 2019; Dotson \& Hyatt, 2005; Mittal, Daga, Chhabra, \& Lilani, 2010; Ramzy et al., 2012) have observed how children persuade or even change their parents buying choices for products under this theory. Sheth (1974) proposed a theory to elucidate parents buying decisions within both joint and autonomous family structures. The theory revolves around three specific parts, which have been considered a basis in the determination of buying patterns. Family consumption, single-member consumptions, and domestic unit consumptions. Further, he explained, if the father initiates the buying decision or has more dominance in the selection of items, children will have more persuasive power to nag their fathers. Besides, if the buying power is not centralized, children will have a direct or indirect influence on the purchase of different product categories towards their parents. Specifically, in the purchase of household products, they are more involved and act as an influencer. McNeal (1999), in his book "the kid's market myths and realities," concluded that the concept of pester power arose as a result of an economic downturn that, touched the inflation in double digits in 1970. In 1980, a massive economic recession also had joined the scene, 
and many families had suffered from financial instability but the effort to provide more to their children in terms of items, money, leisure, and education. To prevent them from any inferiority, parents also empower children as decision-makers in a family buying decision. Furnham, Gunter and, Walsh (1998) inferred that media is one of the significant catalysts that prevails pester power in children. Pester power is build up when parents bring their children shopping, get their opinion, and encourage them to ask for things. This factor makes children demand or pester for things from a very little age instead of picking up from any place they see it. It starts when the parents and children visit some relatives, and the child wishes for playing with toys and games of host family kids (Bridges \& Briesch, 2006; Chaudhary, Durrah, \& Ghouse, 2019).

\section{Hypothesis \& Research Model}

\subsection{Children Peer Influence and Parents Buying Decision}

Askelson et al. (2019) elucidated that parents are more inclined to purchase value for money products. Children's susceptibility to peer pressure is not considered much to influence their parent's buying in low-income families. However, high socio-economic cluster parents are influenced. Besides, Lati, Abrar and Ali (2017) explicated that, children prefer products, used or suggested by their peers due to three underlying reasons: first, they can manage their expenses themselves, second, they have more spending power than their adults, and third, children's loyalty as a young buyer that payback before time and show the tendency of purchasing products used by their peers or friends. In addition to that, Jain and Sharma (2016) delineated, children often put higher pressure on the purchase's items, parents appreciate kid's information, say, regarding products and find it useful when making a purchase decision. Their purchase decisions depend on product color, packaging, store environment, product size, and peer recommendations.

The children's peer influence plays a vital role in parents buying decisions. Every age group possesses a diverse lifestyle, unique culture, mingle way, values, customs, different expectations, and opinions regarding a product. So, marketers need to draw essential marketing strategies, suitable for each age group distinctiveness and behavior, especially, in terms of how to promote the product, its visibility, services, and communication (Khandai \& Agrawal, 2012; O’Neill \& Buckley, 2019; Singh \& Kaur, 2011).

Mokgosa and Mohube (2007) identified that children are vulnerable to peer influence, and they usually show a high propensity to make product choices and buying behaviors endorsed by their peers. The results of their study confirmed the positive correlation between peer influence and children's buying intentions. The research findings reveal that kids accept more pressure and nag their parents for FMCG products rather than other durable products. This mechanism leads to proposing the first hypothesis.

\section{H1: Children's-Peer-Influence positively influences parents buying decisions of FMCG products in Pakistan.}

\subsection{Advertisement Impact on Children and Parents Buying Decision}

Bamfo, Kraa, Asabere, and Atarah (2019) inferred that the importance of advertisement in drawing children buying behavior, brand recognition, and brand choices could not be ignored. Marketers have recognized the power of advertisement in shaping children's behavior as a proactive consumer. Their decumbent nature towards advertisement has paved more opportunities for brands to encounter them with a variety of products. Chaudhary and Hayman (2019) suggest that children's persuasive ability in parents buying decisions largely depends on the nature of product categories. Parents convinced about their children's demand for inexpensive and convenient products. However, it is difficult for children to nag their parents for products that are exclusive and not for their personal use. Advertisement not only persuades children on things that are related to them but also influence children for adult related products such as kitchen items (Jain \& Sharma, 2016). Lati et al. (2017), marketers spent more than $\$ 12$ billion a year on children's targeted advertisements. Their findings showed that children who watch more advertisements strongly nag their parents buying decisions and consume more products. The majority of the parents thought that advertisement is the primary source of information for children to get brand awareness. Parents agreed that children influence their product choices, through diversified strategies more specifically for FMCG products. Other than that, Ramzy et al. (2012) inferred that marketers could influence children by their favorite celebrities in the advertisement, and free prizes are a useful way to draw children's interest and affect their family buying behavior. An advertisement that is designed to target children, induce them to pester their parents, as the advertised products increase demand in children as compared with the unadvertised products. Children always have a greater awareness of the products shown in the advertisement, thereby pester their parents buying choices (Kristensen, 2005). Similarly, Prendergast and Wong (2003) explicated that advertised products have an enormous impact on children's product choices, which in turn has a positive control for a family purchase decision. Children with 3-5 age group, have little understanding of advertisement but have an image of advertised products. Children with the 5-10 age group, have sufficient product awareness, and tend 
to purchase products that are known to them (Turner, 2006).

H2: Effect of advertisement on children positively impact parents buying decisions of FMCG products in Pakistan.

\subsection{Product Packaging Influence on Children and Parents Buying Decision}

Thyne, Robertson, Watkins, and Casey (2019) stated that diverse forces triggered children's stimulation to engage in family buying: advertisement, product designing, and peer influence. Children were found showing strong purchase preferences for brands, having visual aesthetics in packaging. Chatham, Huye, and Landry (2016) elucidated that, usually, kids below twelve years of age are attracted more towards packaging. Packaging with lively colors and cartoon characters attract children's attention and, pester power among them. Charry (2014), visual aids on packaging and children buying for fast food products, he found that visual appeal is one of the most critical components that used by marketers to increase product consumption among children. Children possess fewer capabilities to judge a product based on benefits and attributes, and they only evaluate the product on their attractive packaging and presentation. Similarly, Hollywood, Wells, Armstrong, and Farley (2013) suggested that packaging plays a vital role in attracting child attention and intensifies impulsive buying. Children are more likely to prefer products of wrapper design. FMCG products with plain packaging, enable children to differentiate between products and put influence on parental buying in a repetitive way.

Marshall, O'Donohoe, and Kline (2007) described that active packaging impacts children's and children's influence on their family purchasing. Further, it described that packaging undoubtedly has a substantial impact on child purchase preferences. Similarly, Ahmed and Salman (2005) inferred that also parents endorsed that the packaging had a role in their child product choices. Children start pestering their parents when they see different products with eye-catching packaging, irrespective of product usefulness. Kelly, Turner, and McKenna (2006) explicate that parents found it challenging to refuse their child demand of the products endorsed by their favorite celebrities and cartoon characters displaying their images. Thus, attractive packaging, visual appeal, product shape, distinct signs and symbols, and unusual ingredients in packaging inspire children to attract and ultimately buy the product.

H3: Children's likeability for product packaging positively influence parents buying decision for FMCG products in Pakistan.

\subsection{Children Likability for Store Environment and Parents Buying Decision}

Page, Sharp, Lockshin, and Sorensen (2019) explicated that children's persuasive power is found much stronger in grocery stores than in any other shopping place. The pester part observed that approximately $80 \%$ of the children use their nagging ability for the purchase of FMCG products, out of which parents accepted $50 \%$ of the demands. Children do not have normative control over their parents buying; rather, they adopt various persuasion strategies such as begging, crying, threatening, nagging, and reason (Chaudhary \& Ghous, 2018). Gulati (2017) described that the store environment also had a positive impact on childrens' pester power.

Similarly, Ahmed, Parmar, and Amin (2014) concluded that children prefer to visit stores that are less crowded so that they can easily walk into the stores to learn about the products available and make their decisions. In addition to that, Martensen (2008) discussed the power of children's nagging ability in a different store environment. To determine the strength of children nagging ability on family buying decisions, they visit different stores with distinguishing ambiance. The outcomes of his study showed that most children trigger parents buying decisions in place to act as an influencer. Younger children accept more influence from the store environment and quickly induce their parents as compared to adolescents. Gender does not play a significant role in pester power, and children can apply their nagging ability on almost low-priced products such as food items to high priced products like automobiles (Bridges \& Briesch, 2006). McDermott, O’Sullivan, Stead, and Hastings (2006) examined parent's loyalty for different stores. The majority of the parents reported that they likely visit stores adored by their kids. This factor helps markets to create long term relationships with parents and provide enhanced store experience to children.

H4: Children's likeability for the store environment positively influences parents buying decisions of FMCG products in Pakistan. 


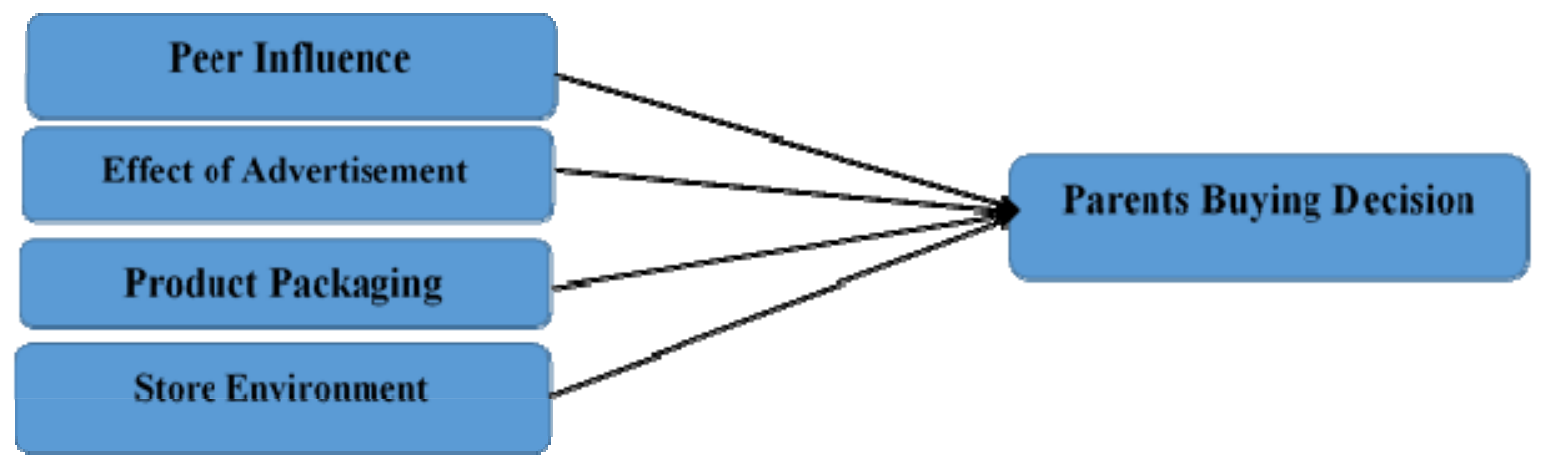

Figure 1. Conceptual model

\section{Method}

\subsection{Sample and Procedure}

To test our proposed hypothesis (Figure 1), 384 questionnaires marked with serial no (1-384) were distributed by hand among the parents, shopping in different malls and supermarkets in Pakistan to meet the sample size requirement (Sekaran \& Bougie, 2016). Parents who had one or more children aged 5-15, and were habitual to shop with their children were part of this survey. The reason for selecting this age group is that they rely on parents purchasing power. The inclusion criteria to identify the right respondents were adopted by incorporating filtering questions in the questionnaire. (See Appendix A). Out of 384 questionnaires, 234 filled questionnaires were returned. All 234 filled questionnaires were examined. Out of that 200 qualified to be subject of analysis. Hence, proving the acceptable response rate of $52 \%$. To address the issue of non-response bias, the data from the first 100 questionnaires were compared with the data of the subsequent 100 questionnaires using the simple t-test. The findings did not reveal any significant differences in both groups on all measures.

\subsection{Measures}

Our research instrument entails 24 items and consists of three sections. In the first section, filtering questions were included to ascertain whether parents have children of 5-15 years of age, the second section asked four demographic questions (e.g., age, gender, qualification, number of children). The third part comprised the independent variable (pester power) and its four dimensions; and the dependent variable (parents buying decision). The research model of this study consists of five constructs established through prior literature. The peer influence construct was measured by three items (PI1-PI3) as used by Jain and Sharma (2016), and the store environment was measured by three items (SE1-SE3) adopted from Haglund and Stenberg (2012). The product packaging scale consists of three items (PP1-PP3), adopted from Jain and Sharma (2016), and the advertisement effect construct was measured by three items (AE1-AE3) used by Lati and Abrar (2017). The dependent variable construct "parents buying decision" construct was measured through 5 items (PB1-PB5), adopted from Nicholls and Cullen (2004) (See Appendix B).

\subsection{Common Method Variance Bias}

In self-reported surveys from a single source, common method variance affects the validity and reliability of the studied constructs and their hypothesized associations in the path model (Fuller, Simmering, Atinc, \& Babin, 2016). To address the issue of common method variance, a procedural and psychological method was employed by including the fun facts in the questionnaire between the measure along with the other procedural measures (Podsakoff, MacKenzie, \& Lee, 2003) (See Appendix C).

\section{Results}

The analysis of collected data was conducted through partial least structural equation modeling technique, because in case of limited data set or not-normal data, PLS-SEM is considered the most appropriate technique, as it produces the robust results (Hair et al., 2019). Moreover, as the focus of this study was predictive and exploratory, the best choice is PLS-SEM. The proposed study model was tested through a two-step approach. At first, the measurement model was tested to ascertain its validity and reliability. In the second step, the structured model was analyzed to test the hypothesized relationships among the model constructs. 


\subsection{Descriptive Analysis}

Table 1 indicates the analysis of respondents' profiles that $40 \%$ of parents were fathers, and $60 \%$ consist of mothers. More than 70\% of the parent's age falls between 25-44 years. Furthermore, 63\% of the Sample size shows the Graduate and Masters Level qualification of parents. A vast majority (81\%) of parents accounted for one or two children, followed by $19 \%$ of respondents who had three and four children. Families with one and two children dominated the results of this study.

\subsection{Measurement Model}

The measurement model validation criteria consist of four factors. Internal Consistency (composite reliability), Indicator Reliability (factor loading), Convergent Validity (average variance extracted) and, Discriminant Validity (HTMT, Fornell \& Larcker's test \& cross-loading) as explained by Hair et al. (2019).

Table 2 demonstrates the composite reliability values of all variables are higher than $0.7(\mathrm{CR}>0.7)$, factor loading on all variables is higher than its acceptable threshold 0.4 , convergent validity scores of all variables demonstrate valid scores of higher than 0.5 (AVE > 0.5) and the model also meets its fourth validity criteria by revealing the discriminant validity on all variables, as the more conservative measure of discriminant validity, the heterotrait-monotrait ratio of correlations (HTMT ${ }_{0.85}$ ) score among the variables is less than threshold .85 (Kline, 1994), as suggested by Henseler, Ringle, and Sarstedt (2015) (see Table 3, Figure 2).

Table 1. Respondents profile

\begin{tabular}{|c|c|c|c|}
\hline Variable & Category & Frequency & Percentage \\
\hline \multirow[t]{2}{*}{ Gender } & Male & 80 & $40 \%$ \\
\hline & - $\quad$ Female & 120 & $60 \%$ \\
\hline \multirow[t]{4}{*}{ Age } & - $\quad 20-24$ & 36 & $18 \%$ \\
\hline & - $\quad 25-34$ & 77 & $38.5 \%$ \\
\hline & - $\quad 35-44$ & 64 & $32 \%$ \\
\hline & - $\quad 45 \&$ above & 23 & $11.5 \%$ \\
\hline \multirow[t]{4}{*}{ Education } & - $\quad$ High School & 13 & $6.5 \%$ \\
\hline & - Intermediate & 60 & $30 \%$ \\
\hline & - $\quad$ Graduate & 63 & $31.5 \%$ \\
\hline & - $\quad$ Post Graduate & 64 & $32.2 \%$ \\
\hline \multirow[t]{4}{*}{ No of Children } & - $\quad$ One & 82 & $41 \%$ \\
\hline & - $\quad$ Two & 80 & $40 \%$ \\
\hline & - $\quad$ Three & 20 & $10 \%$ \\
\hline & - $\quad$ Four or More & 18 & $9 \%$ \\
\hline
\end{tabular}

Table 2. Measurement model analysis

\begin{tabular}{lllll}
\hline Construct & No. Of Items & Factor Loading & CR & AVE \\
\hline PI & 3 & $0.778-0.878$ & 0.856 & 0.666 \\
EA & 3 & $0.672-0.823$ & 0.806 & 0.582 \\
PP & 3 & $0.747-0.823$ & 0.819 & 0.601 \\
SE & 3 & $0.797-0.823$ & 0.849 & 0.652 \\
PBD & 5 & $0.581-0.785$ & 0.828 & 0.504 \\
\hline
\end{tabular}

Note. PI Peer Influence, EA Effect of Advertisement, PP Product Packaging, SE Store Environment, PBD Parents Buying Decision, $C R$ Composite Reliability, AVE Average Variance Extracted.

Table 3. Heterotrait-Monotrait ratio $\left(\operatorname{HTMT}_{0.85}\right)$

\begin{tabular}{llllll}
\hline & EA & PBD & PI & PP & SE \\
\hline EA & & & & & \\
PBD & 0.45 & & & & \\
PI & 0.769 & 0.756 & & & \\
PP & 0.692 & 0.376 & 0.649 & & \\
SE & 0.812 & 0.195 & 0.709 & 0.794 & \\
\hline
\end{tabular}

\subsection{Structural Model}

Although the vertical collinearity (among the indicators) issue was tested by discriminant validity, it is crucial to 
test the lateral collinearity issue among the exogenous variables (predictor-criterion collinearity), because its existence may mislead the findings (Kock \& Lynn, 2012). This study meets the more stringent criteria of all predictors less than its threshold 3.3 (VIF $<3.3$ ), suggested by Diamantopoulos and Siguaw (2006). To assess the accuracy of the model's prediction level, $\mathrm{R}^{2}$ score higher than 0.75 is considered substantial (Hair et al., 2017). The current study's coefficient of determination value for parent's buying decision is 0.893 . Moreover, the predictive relevance of the model was calculated through Stone-Geisser $\mathrm{Q}^{2}$ (cross-validated redundancy). The $\mathrm{Q}^{2}$ score of parents' buying decision (0.424) was higher than zero (Chin, 2010), thus confirming the predictive relevance of the endogenous variable.

The results of hypothesis testing and effect size are displayed in Table 4. The analysis of bootstrapping results demonstrates that the first hypothesis proposed that peer influence positively affects parent buying decisions, and the study results support this $(\beta=0.373, \mathrm{p}<0.001)$. Therefore, $\mathrm{H} 1$ is accepted. Similarly, the second hypothesis proposed that advertisements also affect parents buying decisions positively; the study results suggest that the $\mathrm{H} 2$ also be accepted $(\beta=0.593, \mathrm{p}<0.001)$. The third hypothesis also is accepted as the results showed that product packaging also affects parents buying decisions $(\beta=0.123, \mathrm{p}<0.01)$. Three of the four hypotheses have shown significant results, and only the fourth hypothesis results are not supported $(\beta=0.025, p>0.05)$. Thus, we accept $\mathrm{H} 1, \mathrm{H} 2, \mathrm{H} 3$, and $\mathrm{H} 4$, which are rejected. To assess the effect size of each exogenous variable, peer influence and effect of advertisement have a substantial effect on endogenous, as it is evident from the $\mathrm{f}^{2}$ values of respective variables $(0.802,0.928)$. In contrast, the product packaging has a small effect on parents buying decision $\left(\mathrm{f}^{2}=\right.$ 0.089 ) as the path coefficients of each variable supports the $f^{2}$ values (Hair, Risher, Sarstedt, \& Ringle, 2017) (see Table 4, Figure 2).

Table 4. Path coefficients and hypothesis testing

\begin{tabular}{lllllll}
\hline Hypothesis & Relationship & Path Coefficient & t-values & p-values & $\mathbf{f}^{2}$ (effect size) & Result \\
\hline H1 & PI -> PBD & 0.373 & 9.896 & $0.000^{* * *}$ & 0.802 (large) & Supported \\
H2 & EA -> PBD & 0.593 & 13.826 & $0.000^{* * *}$ & 0.928 (large) & Supported \\
H3 & PP -> PBD & 0.123 & 3.502 & $0.001 * *$ & 0.089 (small) & Supported \\
H4 & SE -> PBD & 0.025 & 0.713 & 0.476 & ------- & Not Supported \\
\hline
\end{tabular}

Note. ${ }^{* *} \mathrm{p}<0.01,{ }^{* * *} \mathrm{p}<0.001$, one tail.

\section{Discussion}

This study investigated the role of pester power in parents buying decisions with the help of four predictors Peer influence, store environment, product packaging, and the effect of advertisement. The results demonstrate that product packaging, peers' product preferences, and advertisements strongly affect parents buying decision of FMCG products. The structural model results are a clear manifestation of how to pester power not only stimulates parents buying but also creates social development and consumerism in children. The study also confirms that the most crucial dimension of pester power is the effects of Advertisement and children's peer influence. This finding is in line with the study of Lati and Abrar (2017). They concluded that as children spend more time watching different programs on television, they get awareness about new products. As a result, they nag their parents to go for those products. Similarly, the study of Jain and Sharma (2016) supports that children's peer influence and advertisement play a key role in developing pester power. Resultantly, parents buying decisions are strongly influenced. Likewise, Gulati (2017) noted that peer influence has the power to influence and even increase the frequency of purchase and catalyst overall buying process. Children's product choices are majorly reflecting by their peer opinion because they want to get fit in their groups. The third hypothesis of this study revealed that the third factor of pester power (product packaging) have significant impact on parents buying decision, though the effect size is small as compared to advertisement effect and peer influence. The study of Farley (2013) supports this theory. He concluded that product packaging plays a vital role in attracting child attention and intensifies impulse buying. Children are more likely to prefer products of wrapper design. FMCG products with distinct packaging enable children to differentiate between products and put influence on parental buying in a repetitive way, which also resembles our results. Jain and Sharma (2016) delineated the same.

The results of the fourth hypothesis are not in line with the findings of Ram and Ravindran (2014). Their study has recognized the store environment as an influencing factor as a pester power. The possible reason can be 1) context differences, as their study was conducted in Indian environment; 2) time lag can be other possible difference, as in today's world children have turned smarter in term of awareness due to social media as they are 
now more focused about products rather than ambiance; 3) population different clusters can be a third possible reason.

\section{Conclusion}

Children have become a very significant group of customers. They influence their parents over family buying decisions and make the shopping process more complicated. Research results showed that various factors cause children to pester their parents in family buying decisions, it may be peer influence, product packaging, size, a shape that attracts them, and particularly advertisements that have a powerful effect on their buying behavior, product choices and spending patterns. At times the pestering factors influencing parents buying decisions are affected by children's age, persuasive strategy, parent's financial position, and occasions. In today's modern world, children have a more significant say in the family buying decisions, and they used different persuasive techniques to pester their parents about their product choices, it is observed that many parents purchase products requested by their children directly and many parents accept children demands to make them happy or to avoid any hassle at shopping place. Furthermore, parents fulfill children's demand for inexpensive products, and for expensive products, they try to induce children to accept their choices. Children are sharp spectators, they experience new products, lack brand loyalty, and are a substantial part of the family. Therefore, Marketers want to promote their products by targeting children to stimulate them to induce their parents buying decisions and buy new products

\subsection{Managerial Implications}

The increasing consumerism in children makes them more confident about their product choices. They actively take part in family buying and have exceptional knowledge of the products more than their parents. As they know that parents will fulfill their demands, that is why they do not want to compromise. In today's world, where children spend most of their time with electronic gadgets, it becomes elementary for marketers to promote their products with kids. Marketers should design the product in such a way that it attracts children's attention. Using vibrant colors, favorite cartoon characters in packaging will be helpful to memorize a product, and pestering parents to purchase decisions. Additionally, marketers can also get benefit from pester power by targeting children for expensive products and for the products that are not related to them.

\subsection{Limitations}

The first limitation of the research is its limited sample size, which may deviate the outcomes to some degree. The Data were collected from a single source (parents) only. Children not only influence their parents buying decisions but also their elder siblings such as brother, sisters, and other family members; that is why the sample size does not represent the entire population; future research may take this into account. Second, this study focused on FMCG products, and future research can be executed in different industries such as the fast-food industry, apparel brands, and other to measure children's nagging ability with larger sample sizes to produce more accurate results. Third, researchers can take some other variable such as impulse buying, child marketing, children nagging factor in different product categories. Last, future research may examine the degree of pester power in the context of the gender of children.

\section{References}

Ahmed, A., \& Salman, A. (2005). Critical issues in packaged food business. British Food Journal, 107(10), 760-780. https://doi.org/10.1108/00070700510623531

Ahmed, R., Parmar, V., \& Amin, A. (2014). Impact of Product Packaging on Consumer's Buying Behavior. European Journal of Scientific Research, 120(2), 145-157. Retrieved from $\mathrm{http}: / / \mathrm{www}$. europeanjournalofscientificresearch.com/issues/EJSR_122_2,html

Arul \& Vasudevan, V. (2016). Influence of children on parents buying behavior. Journal of Cost and Management, 44(1), 19-23.

Askelson, N. M., Golembiewski, E. H., Meier, C. L., Smith, R., Montgomery, D., Lillehoj, C. J., \& Wilson, S. (2019). Pester Power: Understanding Parent-Child Communication About Fruits and Vegetables in Low-Income Families from the Child's Perspective. Social Marketing Quarterly, 25(3), 182-192. https://doi.org/10.1177/1524500419839497

Bamfo, B. A., Kraa, J. J., Asabere, P., \& Atarah, B. A. (2019). Effect of television adverts on children's purchase behavior: Evidence from Ghana. Cogent Business \& Management, 6(1), 1614740. https://doi.org/10.1080/23311975.2019.1614740

Bridges, E., \& Briesch, R. A. (2006). The 'nag factor' and children's product categories. International Journal of 
Advertising, 25(2), 157-187. https://doi.org/10.1080/02650487.2006.11072961

Calvert, S. L. (2015). Children as consumers: Advertising and marketing. The Future of Children, 18(1), 205-234. https://doi.org/10.1353/foc.0.0001

Charry, K. (2014). The impact of visual and child-oriented packaging elements on children's purchase influence across various age groups. International Journal of Retail and Distribution Management, 42. https://doi.org/10.1108/IJRDM-08-2013-0159

Chatham, C., Huye, H. F., \& Landry, A. S. (2016). Impact of Packaging on Children's Food Choices. Journal of the Academy of Nutrition and Dietetics, 116(9), A22. https://doi.org/10.1016/j.jand.2016.06.066

Chaudhary, M., Durrah, O., \& Ghouse, S. M. (2019). Young consumer's influence: A study of the Gulf region. Journal of Islamic Marketing. https://doi.org/10.1108/JIMA-04-2018-0068

Chaudhury, S. R., \& Hyman, M. (2019). Children's influence on consumption-related decisions in single-mother families: Research review and Agenda. Cogent Business \& Management, 6(1), 1622178. https://doi.org/10.1080/23311975.2019.1622178

Chin, W. W. (2010). How to write up and report PLS analyses. In Handbook of partial least squares (pp. 655-690). Springer, Berlin, Heidelberg. https://doi.org/10.1007/978-3-540-32827-8_29

Diamantopoulos, A., \& Siguaw, J. A. (2006). Formative versus reflective indicators in organizational measure development: A comparison and empirical illustration. British Journal of Management, 17(4), 263-282. https://doi.org/10.1111/j.1467-8551.2006.00500.x

Dikčius, V., Pikturnienè, I., Šeimienė, E., Pakalniškienè, V., Kavaliauskè, M., \& Reardon, J. (2019). Who convinces whom? Parent and child perceptions of children's engagement in parental purchase decisions. Journal of Promotion Management, 25(2), 252-269. https://doi.org/10.1080/10496491.2018.1443306

Dotson, M. J., \& Hyatt, E. M. (2005). Major influence factors in children's consumer socialization. Journal of Consumer Marketing, 22(1), 35-42. https://doi.org/10.1108/07363760510576536

Fuller, C. M., Simmering, M. J., Atinc, G., Atinc, Y., \& Babin, B. J. (2016). Common methods variance detection in business research. Journal of Business Research, 69(8), 3192-3198. https://doi.org/10.1016/j.jbusres.2015.12.008

Furnham, A., Gunter, B., \& Walsh, D. (1998). Effects of program context on the memory of humorous television commercials. Applied Cognitive Psychology: The Official Journal of the Society for Applied Research in Memory and Cognition, 12(6), 555-567. https://doi.org/10.1002/(SICI)1099-0720(1998120)12:6<555::AID-ACP537>3.0.CO;2-X

Gulati, S. (2017). Impact of Peer Pressure on Buying Behavior. International Journal of Research-Granthaalayah, 5(6), 280-291.

Haglund, J., \& Stenberg, S. (2012). Children's Influence-Regarding Home Delivery Grocery Bags with Family food Optima AB in Focus. from http://www.diva-portal.se/smash/get/diva2:543590/FULLTEXT01.pdf

Hair, J. F., Risher, J. J., Sarstedt, M., \& Ringle, C. M. (2019). When to use and how to report the results of PLS-SEM. European Business Review. https://doi.org/10.1108/EBR-11-2018-0203

Hair, Jr, J. F., Sarstedt, M., Ringle, C. M., \& Gudergan, S. P. (2017). Advanced issues in partial least squares structural equation modeling. Sage publications. https://doi.org/10.1007/978-3-319-05542-8_15-1

Henseler, J., Ringle, C. M., \& Sarstedt, M. (2015). A new criterion for assessing discriminant validity in variance-based structural equation modeling. Journal of the Academy of Marketing Science, 43(1), 115-135. https://doi.org/10.1007/s11747-014-0403-8

Hollywood, L., Wells, L., Armstrong, G., \& Farley, H. (2013). Thinking outside the carton: attitudes towards milk packaging. British Food Journal, 115(6), 899-912. https://doi.org/10.1108/BFJ-Jul-2010-0127

Jain, N., \& Sharma, N. (2016). Measuring the Effect of Pester Power on Family Buying Decision in FMCG Products Using Factor Analysis. Imperial Journal of Interdisciplinary Research, 2(4), 192-199. Retrieved from https://www.academia.edu/34967845/Measuring_the_Effect_Of_Pester_Power_on_Family_Buying_Decisi on_in_FMCG_Products_Using_Factor_Analysis

Kelly, J., Turner, J. J., \& McKenna, K. (2006). What parents think: children and healthy eating? British Food 
Journal, 108(5), 413-423. https://doi.org/10.1108/00070700610661376

Khandai, S., \& Agrawal, B. (2012). Impact of television commercials upon the purchase behavior of urban Indian children. International Journal of Marketing and Technology, 2(4), 72.

Kline, P. (1994). An Easy Guide to Factor Analysis. Psychology Press.

Kock, N., \& Lynn, G. (2012). Lateral collinearity and misleading results in variance-based SEM: An illustration and recommendations. Journal of the Association for Information Systems, 13(7). https://doi.org/10.17705/1jais.00302

Kristensen, M. (2005). Cross-resistance between dieldrin and fipronil in the German cockroach (Dictyoptera: Blattellidae). Journal of Economic Entomology, 98(4), 1305-1310. https://doi.org/10.1603/0022-0493-98.4.1305

Lati, I., Abrar, M., \& Ali, M. (2017). Influence of Advertising, Parent power, Environment, and Kids buying behavior on Pester Power. Global Journal of Research in Business \& Management, 6(2), 469-472.

Lawlor, M. A., \& Prothero, A. (2011). Pester power-A battle of wills between children and their parents. Journal of Marketing Management, 27(5-6), 561-581. https://doi.org/10.1080/0267257X.2010.495281

Makgosa, R., \& Mohube, K. (2007). Peer influence on young adults' products purchases decisions. African Journal of Business Management, 1(3).

Marshall, D., O'Donohoe, S., \& Kline, S. (2007). Families, food, and pester power: beyond the blame game? Journal of Consumer Behavior, 6(4), 164-181. https://doi.org/10.1002/cb.217

Martensen, A., \& Gronholdt, L. (2008). Children's influence on family decision making. Innovative Marketing, $4(4), 14-22$.

McDermott, L., O’Sullivan, T., Stead, M., \& Hastings, G. (2006). International food advertising pesters power and its effects. International Journal of Advertising, 25(4), 513-540. https://doi.org/10.1080/02650487.2006.11072986

McNeal, U. J. (1999). The kid's market myths and realities. Itchaca: NY Paramount Market Publishing, Inc.

Mittal, M., Daga, A., Chhabra, G., \& Lilani, J. (2010). Parental Perception of the Impact of Television Advertisements on Children's Buying Behavior. IUP Journal of Marketing Management, 9(1/2), 40.

Nicholls, A. J., \& Cullen, P. (2004). The child-parent purchase relationship: "pester power," human rights and retail ethics. Journal of Retailing and Consumer Services, 11, 75-86. https://doi.org/10.1016/S0969-6989(02)00080-2

O’Neill, C., \& Buckley, J. (2019). "Mum, did you just leave that tap running?" The role of positive pesters power in promoting sustainable consumption. International Journal of Consumer Studies, 43(3), 253-262. https://doi.org/10.1111/ijcs.12505

Ogba, I. E., \& Johnson, R. (2010). How packaging affects the product preferences of children and the buyer behavior of their parents in the food industry. Young Consumers, 11(1), 77-89. https://doi.org/10.1108/17473611011026037

Page, B., Sharp, A., Lockshin, L., \& Sorensen, H. (2019). Using the eyberg child behavior inventory to investigate pester power. Journal of Retailing and Consumer Services, 47, 265-271. https://doi.org/10.1016/j.jretconser.2018.12.004

Pakistan statistics Bureau. (2019). Retrieved from http://www.pbs.gov.pk/content/population-census

Podsakoff, P. M., MacKenzie, S. B., Lee, J. Y., \& Podsakoff, N. P. (2003). Common method biases in behavioral research: A critical review of the literature and recommended remedies. Journal of Applied Psychology, 88(5), 879. https://doi.org/10.1037/0021-9010.88.5.879

Prendergast, G., \& Wong, C. (2003). Parental influence on the purchase of luxury brands of infant apparel: an exploratory study in Hong Kong. Journal of Consumer Marketing, 20(2), 157-169. https://doi.org/10.1108/07363760310464613

Ram, H., \& Ravindran, S. S. (2014). Entertainment Area and its Relevance in Inducing Pester Power a Study with Reference to Chic King Outlet. International Journal of Scientific Research, 3(4), 1-3. https://doi.org/10.15373/22778179/APR2014/233

Ramzy, O., Ogden, D. T., Ogden, J. R., \& Zakaria, M. Y. (2012). Perceptions of children's influence on purchase 
decisions empirical investigation for the US and Egyptian families. World Journal of Management, 4(1), $30-50$.

Sekaran, U., \& Bougie, R. (2016). Research methods for business: A skill-building approach. John Wiley \& Sons.

Sheth, J. N. (1974). A theory of family buying decisions. Models of Buyer Behavior, 17-33.

Singh, S., \& Kaur, J. P. (2011). The Impact of Advertisements on Children and Their Parents' Buying Behavior: An Analytical Study. IUP Journal of Marketing Management, 10(3), 18.

Thomson, E. S., Laing, A. W., \& McKee, L. (2007). Family purchase decision making: Exploring child influence behavior. Journal of Consumer Behavior: An International Research Review, 6(4), 182-202. https://doi.org/10.1002/cb.220

Thyne, M., Robertson, K., Watkins, L., \& Casey, O. (2019). Retailers targeting children with set collection promotions: the child's perspective. International Journal of Retail \& Distribution Management, 47(6), 643-658. https://doi.org/10.1108/IJRDM-08-2017-0180

Turner, J. (2006). Food for thought: parents' perspectives of child influence. British Food Journal, 108(3), 181-191. https://doi.org/10.1108/00070700610651007

\section{Appendix A}

\section{Filtering Questions}

\begin{tabular}{ll}
\hline Filtering/ Screening Question & Inclusion Criteria \\
\hline $\begin{array}{l}\text { Q1 What is Your Marital Status? } \\
\text { (If married, answer the next question) }\end{array}$ & Married \\
$\begin{array}{l}\text { Q2 Are you a parent of child/children of 5-16 years old? } \\
\text { (if yes, answer the next question) }\end{array}$ & Yes \\
$\begin{array}{l}\text { Q3 Are you habitual/always take your child/children along when going to shop? } \\
\text { (if yes, then fill the questionnaire) }\end{array}$ & Yes \\
\hline
\end{tabular}

\section{Appendix B}

\section{Measurement Model Questionnaire}

\begin{tabular}{|c|c|c|}
\hline Construct \& Item Code & Questionnaire & Supporting Literature \\
\hline Peer Influence & Your kid buys the same brands as his friends buy. & Jain and Sharma (2016) \\
\hline $\mathrm{PI}_{1}$ & Your kid thinks, "It is important for him to fit in with his friends." & \\
\hline $\mathrm{PI}_{2}$ & It bothers your kid when his friends have something he does not have. & \\
\hline \multicolumn{3}{|c|}{ 1 - } \\
\hline Store Environment & Your kid has his favorite stores at which to shop. & Haglund and Stenberg \\
\hline $\mathrm{SE}_{1}$ & Your kid likes to shop in a store that's not crowded. & $(2012)$ \\
\hline $\mathrm{SE}_{2}$ & Your kid likes to shop in supermarkets or large retail stores from where he/she & \\
\hline $\mathrm{SE}_{3}$ & can select products of his/her own choice. & \\
\hline Product Packaging & You think bright Color, packaging, or presentation of the products influence & Jain and Sharma (2016) \\
\hline $\mathrm{PP}_{1}$ & your kid's purchase. & \\
\hline $\mathrm{PP}_{2}$ & Your kid gets influenced by the size of the packaging & \\
\hline $\mathrm{PP}_{3}$ & $\begin{array}{l}\text { Your kid's product preferences are influenced by-products of specific characters } \\
\text { on the packaging. }\end{array}$ & \\
\hline $\begin{array}{l}\text { Effect of Advertisement } \\
\text { EA }_{1}\end{array}$ & $\begin{array}{l}\text { You think your children desire those products which they have seen in the } \\
\text { advertisement. }\end{array}$ & Lati \& Abrar (2017) \\
\hline $\mathrm{EA}_{2}$ & You think your kid's demand has increased because of greater exposure through & \\
\hline \multirow[t]{2}{*}{$\mathrm{EA}_{3}$} & advertisement. & \\
\hline & $\begin{array}{l}\text { Do you think advertisements in which children appear both those designed to } \\
\text { sell children's products and those designed to persuade adults influence children } \\
\text { to purchase? }\end{array}$ & \\
\hline Parents Buying Decision & Your kid values your (parents) opinion of what he/she buys. & Nicholls \& Cullen \\
\hline $\mathrm{PBD}_{1}$ & Your kid thinks that you (parents) should have to say what he/she buys. & (2004) \\
\hline $\mathrm{PBD}_{2}$ & You often buy products choose by your kid. & \\
\hline $\mathrm{PBD}_{3}$ & Your opinion is more important for kids rather than his/her friends. & \\
\hline $\mathrm{PBD}_{4}$ & Your kid buys the same brand as you buy. & \\
\hline $\mathrm{PBD}_{5}$ & & \\
\hline
\end{tabular}




\section{Appendix C}

\section{Procedural Technique for Common Method Bias}

\begin{tabular}{ll}
\hline Procedural Techniques & a. Fun Facts were included in the questionnaire at every section \\
& b. All respondents were assured of the confidentiality of their response \\
c. Respondents were communicated that there are no right or wrong answers \\
Fun Facts & a. Do you know North Korea and Cuba are the only places you cannot buy Coca-Cola? \\
b. Do you know there is only one letter that does not appear in any U.S. state name? \\
c. Do you know Scotland has 421 words for "snow"? \\
d. Do you know the longest English word is 189,819 letters long? \\
e. You filled in the questionnaire 100\%. Thank you for your support and patience
\end{tabular}

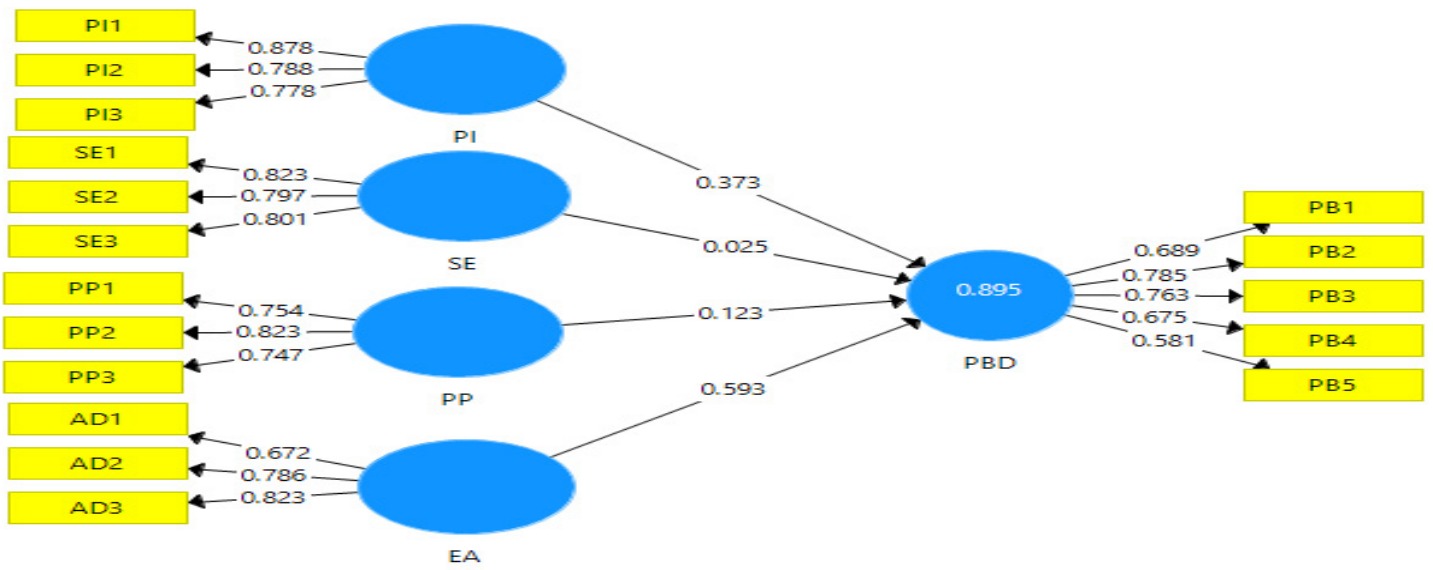

Figure 2. Path model

\section{Copyrights}

Copyright for this article is retained by the author, with first publication rights granted to the journal.

This is an open-access article distributed under the terms and conditions of the Creative Commons Attribution license (http://creativecommons.org/licenses/by/4.0/). 